\title{
Policy-Oriented Learning: A Case on Initiating Long-Term Care Insurance in China's Social Security Sector
}

\author{
Jian Zhang ${ }^{1}$, Xiao $\mathrm{Yu}^{2}$ and Yanzhe Zhang ${ }^{2, *}$ \\ 1 Department of Marketing, School of Management, Changchun Institute of Technology, \\ Changchun 130012, China; jianzhangccit@sina.com \\ 2 Northeast Asian Research Center, Jilin University, Changchun 130012, China; yux@jlu.edu.cn \\ * Correspondence: yanzhe_zhang@jlu.edu.cn; Tel.: +86-183-4048-1717
}

check for updates

Citation: Zhang, J.; Yu, X.; Zhang, Y. Policy-Oriented Learning: A Case on Initiating Long-Term Care Insurance in China's Social Security Sector. Sustainability 2021, 13, 3233. https://doi.org/10.3390/su13063233

Academic Editor:

Jesús-Nicasio GarcíA-Sánchez

Received: 3 February 2021

Accepted: 11 March 2021

Published: 15 March 2021

Publisher's Note: MDPI stays neutral with regard to jurisdictional claims in published maps and institutional affiliations.

Copyright: (C) 2021 by the authors Licensee MDPI, Basel, Switzerland. This article is an open access article distributed under the terms and conditions of the Creative Commons Attribution (CC BY) license (https:/ / creativecommons.org/licenses/by/ $4.0 /)$.

\begin{abstract}
This paper explores the initiation process of the long-term care insurance (LTCI) policy in China's social security sector, and focuses on policy-oriented learning activities to develop initiatives from German lessons. It presents a case from the LTCI pilot program, which serves as a new policy product that provides care to the elderly and disabled and upgrades the social security sector's performance. This study implements policy-oriented learning to construct an analytical framework and applies it to China's social security system. This research suggests that policy-oriented learning is a rational tool used to manufacture policy products that enable intellectual development and can provide roadmaps for administrative reform. The findings contribute to the current knowledge on policy-oriented learning by offering new insights from China's experience with LTCI, thus helping to fill the gaps that are created when policy-oriented learning is applied to different systems and contexts, with unique cultural, traditional, and political characteristics.
\end{abstract}

Keywords: policy-oriented learning; Chinese aging problem; China's social security sector; long-term care insurance

\section{Introduction}

China's long-term care insurance (LTCI) pilot program is the largest policy product for addressing the Chinese government's need to face the problem of an aging society, and simultaneously reflects China's strategy of promoting the performance of services that provide care to the elderly and disabled. Since the early 1960s, China has witnessed a significant demographic change [1]. The encouragement for increasing the fertility rate to create a massive population lasted until the late 1970s in order to provide adequate labor levels. With the increase in the population, the issues of food problems, imperfect mechanisms of education resources, limited medical treatment to citizens, etc., became more and more severe. The One-Child Policy was designed to deal with these issues and was first implemented in 1979 [2]. The One-Child Policy worked effectively in the shortterm, but has already generated many negative effects on the current situation in China's development. This has resulted in an aging society, empty nests, and imperfect mechanisms of providing services to the elderly and disabled, which have become huge challenges to both the Chinese government and society. Therefore, the question of how to initiate an efficient and sustainable LTCI has become an important social issue in developing China's social security sector and society, and new initiatives, such as the LTCI pilot program, have been facilitated by drawing on lessons from Western examples, such as Germany, in order to consider policy adaptation in China.

Germany's LTCI has produced significant achievements in social reform since 1994 [2]. Germany's LTCI is an effective and precise system that covers financing, beneficial terms, cost control, quality assurance, and other aspects. It has effectively reduced nursing pressures for residents and has improved the quality of life of patients. Due to the similar demographic structure and culture of providing care to family members, Germany's 
LTCI has become a useful point of reference in the field of providing care to the elderly and disabled [2,3]. Furthermore, its LTCI has achieved positive outcomes because it incorporates dynamic variables during the management process to adjust Germany's social security system.

The theoretical framework of this paper is policy-oriented learning. Policy-oriented learning has progressed in China, specifically in social security and long-term care issues. The nation has learned that fixing the substantial policy failures of the past, given the deep-rooted structural and cultural practices, cannot be completed in haste. New institutionalizations of policy-oriented learning and the adoption of a sounder social policy, with remedial and advancing policy initiatives concerning social security and long-term care policies, are imperative and cannot be completed quickly. Every learning initiative, once implemented, has its own intended and unintended consequences. Sometimes, a solution to a problem may cause problems of its own, whereas problems may generate solutions as different ideas and actors enter the process. The dialectical dynamics of change and stability, disorder and order, and the adoption of an extreme policy initiative with rigidity (which produces its own antithesis to abandon it) not only cause concern regarding policy-oriented learning, but can also be costly and disruptive.

There are many similarities between China and Germany's aging societies (Table 1). First, when Germany and China initiated LTCI, the demographic structures of the two countries were similar. The proportion of elderly people aged over 65 was $15.31 \%$ when Germany's LTCI was introduced in 1994, while it was 16.7\% in China in 2016 [2]. Second, China and Germany share a traditional filial piety culture, and the family is the main body providing care for the elderly and disabled. Third, both China and Germany were in a transition period of their welfare system's reform when they introduced LTCI into their social security sectors. Finally, the main aim of establishing LTCIs in both Germany and China was to fulfill the development needs of the social security sector and society [2]. Therefore, the initiation of the LTCI in China is a good example of a complex "hybrid" form of policy-oriented learning, in which lessons have been learned from Germany.

Table 1. Long-term care insurance (LTCI) policy in Germany and China.

\begin{tabular}{ccc}
\hline Feature & Germany & China \\
\hline Formation & 1994 & 2016 \\
\hline Proportion of elderly people aged over 65 & $15.31 \%(1994)$ & $16.7 \%(2016)$ \\
\hline Main care provider & Family & Family \\
\hline Welfare stage & Deflation period & Transitional period \\
\hline Reason & Social relief and aid to aging society & Social relief and aid to aging society \\
\hline Implementation & Legislation & Policy pilot \\
\hline
\end{tabular}

Source: Developed from [4].

The findings of this study support the official implementation of China's LTCI. It addresses the issue of providing care to disabled and elderly people, and improves the development of the social security sector in China. This study is among the first to explore the initiation process of China's LTCI, and to suggest that policy-oriented learning is a rational analytical framework for establishing policy instruments for dealing with public problems. In addition, this paper observed that policy agents, such as the Ministry of Human Resource and Social Security (MOHRSS), the Ministry of Civil Affairs (MOCA), the United Nations (UN), the World Health Organization (WHO), and the Organization for Economic Co-operation and Development (OECD), play key roles in the internationalization of public sector reform. In doing so, this study contributes to the burgeoning policy-oriented learning literature, which has previously paid little attention to the situation in China.

The remainder of this paper is organized as follows. Section 2 covers the research area, methodology, and data collection; Section 3 provides the background of initiating China's 
LTCI; Section 4 provides a literature review of prior studies; Section 5 explains why the initiation of China's LTCI is a process of policy-oriented learning; Section 6 aims to validate policy-oriented learning during the process of initiating China's LTCI.

\section{Methods and Materials}

Most previous studies have been conducted using LTCI as an approach that promotes the mechanism of providing care to the elderly and disabled. However, they lack an in-depth understanding of how the LTCI was initiated in China, considering both issues of the exogenous lessons and endogenous settings. In order to understand the situation of China's social security, China's demographic characteristics, and how policy-oriented learning worked in initiating the LTCI in China, a methodology was constructed to underlie this study. When investigating how policy-oriented learning engaged in the process of initiating China's LTCI and the outcomes of this policy instrument, the selection of an appropriate research design was critical. It is important to reiterate the research questions that this paper seeks to test and analyze.

Policy-oriented learning is a rational analytical framework and administrative tool for promoting the development of the social security sector and processing the initiation of China's LTCI. Hence, this study developed three research questions: (1) What is the situation and the characteristics of China's aging problem?; (2) Is policy-oriented learning a rational tool for solving the problems caused by China's aging society?; (3) Is the LTCI policy a product of policy-oriented learning in China? An in-depth study of the initiative process used for Germany's LTCI can provide a useful reference for China's government and social security sector to fulfill their desire to initiate long-term care.

Based on the significant gap in the current research and practice, this paper aimed to assess whether a policy-oriented learning framework can facilitate a "short-cut", "readymade", and quick solution to the public problems such as aging society. There are three hypotheses that are addressed in this research. First, policy-oriented learning approaches the creation and implementation of the LTCI in China. Second, policy-oriented learning can engage in supervising the policy making process in China. Third, policy-oriented learning is used as a tool in developing China's social security sector.

This study adopted a mixed-method approach for collecting data, and the material herein is partly based on a radical analysis of the available documents and various online resources. Relevant data concerning national social security, economy, politics, and social issues in China from international organizations, non-governmental organizations (NGOs), and governments, including the MOHRSS, the MOCA, the UN, the WHO, and the OECD, were used. This study drew extensively on Chinese government documents, such as those of the National Bureau of Statistics of China. The authors also conducted personal communications with senior officials and experts of the social security sectors in China. These interviews took place in Beijing, Shanghai, and Shenyang in the second half of 2019. Each of them lasted for approximately one hour and was conducted in Mandarin. The authors were not allowed to record them. As such, they took extensive notes, and the quotations used in this article were recorded verbatim and translated by the principal author, whose first language is Chinese.

\section{Background to the Initiation of China's LTCI Policy and the Social Security Sector's Administrative Reform}

In 2000, China had the largest population in the world at more than 1.3 billion [3], which reached 1.40005 billion by the end of 2019 [5]. According to the National Bureau of Statistics [6], China had 241 million people aged over 60, accounting for $17.3 \%$ of the total population by the end of 2017. This makes China the only country where the number of elderly people exceeds 200 million. It is estimated that China's elderly population will reach approximately 490 million by the end of 2020; Barlett and Phillips predicted that one in eight Chinese will likely be over 70 by this time [7]. Against this aging population background, the number of elderly people who are disabled, empty-nesters, solitary, or have various chronic diseases is increasing. There is a need to provide elderly people with 
long-term care services because of the decline in family pensions caused by multiple factors, such as the continuous increase in medical expenses for the elderly, the requirement for continuous improvements in care quality, a decrease in family population, and unsound social security systems (including pension and medical care), which have significantly increased the burden on pension care.

Therefore, the WHO stated that China needs to establish a long-term care initiative to tackle the issue of providing care to the elderly and disabled [8]. Long-term care insurance (LTCI)is one of the most effective methods for solving these problems and can satisfy the needs of the elderly and reduce the economic burden on both the social security sector and families. To establish long-term care insurance and to improve the development of the social security sector in China, the lessons and experiences of the healthcare sectors from other developed countries have become a major source of learning for the Chinese government [9]. The MOHRSS and the MOCA engage in the process of policy-oriented learning, which has facilitated the initiation of LTCI in China. The pilot program of China's LTCI was launched by the MOHRSS on 27 June 2016 [10], thus confirming its official launch. In summary, China's LTCI is a result of policy-oriented learning and the development of China's social security sector.

\subsection{Aging Problems and Family Issues}

In traditional Chinese culture, the family unit usually carries most of the responsibility for the welfare of family members. However, with the development of the economy and urbanization, LTCI is a new policy instrument that has replaced and addressed the family function in managing aging problems and social security concerns [11]. According to the National Bureau of Statistics, in 2007 there were 153 million people aged 60 and above, accounting for $11.6 \%$ of the total population. At the end of 2018, there were 330 million people aged 60 and above, accounting for $19.0 \%$ of the total population. The number of elderly people more than doubled in 10 years. There are nearly 40 million disabled and partially disabled elderly people in China, including nearly 10 million completely disabled elderly people [5]. The increasingly severe aging of China's population is in line with the acceleration of the implementation of medical, nursing, and long-term care initiatives. Limited by past economic terms, an unbalanced level of medical care, and the increasing number of chronic diseases affecting elderly people, treatment and support cannot meet the requirements of modern elderly care with the social security system. Therefore, it is highly likely that China will initiate a universal and equitable welfare system while maintaining a high growth rate. The absence of technical experience in China necessitates policy-oriented learning from overseas examples. However, the situation has been exacerbated by the One-Child Policy, new demographic patterns, and a cultural shift.

\subsubsection{The One-Child Policy}

Since the founding of the People's Republic of China (PRC), the first generation of Chinese political elites and policy-makers believed that a large population would provide sufficient labor to build a new China. However, the second generation of the Chinese government, led by Deng Xiaoping, thought that over-population and surplus labor was leading to unemployment, shortages in food and clothes, and the underdevelopment of the economy. Hence, Deng's administration initiated the One-Child Policy in 1978, which aimed to limit the population to below 1.3 billion by the end of the 20th century [12]. In the short term, the policy greatly improved economic conditions and alleviated the disparity between China's population and the available resources. It also potentially facilitated a kind of economic boom that has promoted China to being the second largest economy in the world. However, the negative consequences of the One-Child Policy have accumulated long-term adverse impacts on Chinese society.

One of the main negative consequence is the resulting aging society in China: From 2022 to 2035, China will face a serious situation as a result of the increasing number of elderly people, with an annual net increase of 11.52 million and a $3.41 \%$ annual growth 
rate. The total number of elderly people will reach 420 million by 2035 [7]. Nowadays, the children of the first generation of the One-Child Policy represent the main force of Chinese labor, and their parents have retired and are in a period of ill health. Due to the increasing life expectancy, they must provide support and care for their parents and possibly their grandparents. This is called the " $4-2-1$ " problem. This suggests that one child must provide care for at least two older people in their family [13]. This has placed Chinese society and youths at serious risk regarding the physical, mental, and financial burdens of providing care to the disabled and elderly, especially in rural areas, where the elderly rely heavily on their families.

\subsubsection{New Demographic Patterns}

Nowadays, children are no longer able to provide care to their parents, as was done traditionally, due to population mobility, which includes work, immigration, and marriage [14]. China's urbanization process is still experiencing a period of rapid development. Therefore, large-scale population mobility will remain a remarkable phenomenon in the process of socioeconomic development for a long time.

Furthermore, women, who were traditionally the main care providers to the elderly and disabled at home, currently represent the majority of modern labor. Moreover, life expectancy has increased since the foundation of the PRC due to the development of society and the improvement of medical conditions. In 1953, the life expectancy of men was 42.2 years, and 45.6 years for women. In 2018, it reached 73.6 years for men and 79.4 years for women [15], almost doubling in the past 50 years. In summary, new demographic patterns, including population mobility and increased life expectancy, have had a prominent influence on the introduction of LTCI in China.

\subsection{Germany's LTCI Solution}

At the end of the 1980s, Germany's aging society situation was severe. Of the 370,000 elderly and disabled, 70\% could not afford medical treatment and nursing care. In 1994, the German government enacted the Pflege-Versicherungsgesetz due to poverty among the elderly and disabled, the increasing unemployment rates, and the high cost of nursing care. Thus, Pflege-Versicherungsgesetz became the milestone of the German LTCI policy and the development of the social security sector [16]. It aims to relieve the burden on society and families who care for the elderly and disabled. It abides by the principle that "care insurance follows medical insurance," and requires every citizen participating in medical insurance to participate in LTCI. At the turn of the new millennium, over $80 \%$ of the beneficiaries were aged 65 or above, and more than $55 \%$ of the beneficiaries were aged 80 or above. Before the Pflege-Versicherungsgesetz was enacted, $80 \%$ of elderly people aged over 65 who lived in a nursing home could not afford the fees and charges [17]. Thus, the Pflege-Versicherungsgesetz provides financial assistance to elderly people from the social security sector, which is funded by national and local governments.

\subsection{Initiating China's LTCI Policy Pilot Program}

A dramatic increase in the aging population in China has led to the need for an LTCI policy to moderate the problem of an aging society and the financial burden of providing care to the elderly and disabled. Furthermore, the problem of the aging society and the negative impact of the One-Child Policy have become salient issues that will inform Chinese social stability and sustainability in the future [16]. In June 2016, the MOHRSS published a document titled "Guidance on pilot cities to launch long-term care insurance" that emerged from an attempt to meet these challenges, featuring the participation of 31 ministerial- and provincial-level administrative institutes, including the All-China Federation of Trade Union (ACFTU), the China Enterprise Association (CEA), the Ministry of Civil Affairs (MCA), and some related government agencies [11]. This signified the official implementation of the LTCI policy in China [12]. Consequently, China's LTCI commenced in 2016, and 15 cities, i.e., Chongqing, Shanghai, Anqing, Changchun, 
Chengde, Chengdu, Guangzhou, Jiangmen, Nantong, Ningbo, Qingdao, Qiqihaer, Suzhou, Shangrao, and Shihezi, were appointed to implement the pilot program.

Since its implementation, the pilot program has enhanced the performance of the social security sector in relieving the problem of providing care to elderly and disabled people, while it has developed the capacity of the MOHRSS in encouraging the participation of NGOs in the social welfare industry. In sum, the LTCI initiative has made a significant contribution to modernizing China's social security sector, although serious problems remain.

\section{Literature Review and Theoretical Framework}

In 1974, Heclo introduced policy-oriented learning as a term within public policy [18]. It refers to the relatively durable alteration of thought or behavioral intentions that result from experiences that are concerned with the attainment (or revision) of public policy. Since then, many scholars have addressed the policy-oriented learning issue in terms of institutional theory, institution building, and globalization, from a wide range of perspectives, such as bandwagoning [19], convergence [6], diffusion [20], transfer [21], lessondrawing [22], evidence-based practice [23], and learning [24]. These forms of policyoriented learning have been identified in the evolving dynamics of the literature, and have attracted significant academic attention from three perspectives: domestic [25], comparative [26], and international [2], as well as from public management experts across the world [27]. The application of policy-oriented learning is inseparable from the theory of lesson-drawing as the phenomenon of policy transfer develops. Like the study of lesson-drawing, policy-oriented learning emerges when policy-makers are under domestic pressure to seek an international "ready-made solution" [28]. In general, policy transfer is a container concept that refers to knowledge concerning institutions, policies, or the way in which policies are delivered. It varies from one country to another and, increasingly, from one sector to another within each government. Several studies have contributed to a better understanding of the effectiveness of policy-oriented learning and policy development in a country like China [16]. These contributions have laid the foundation and highlighted the need to conduct systematic studies of policy-oriented learning in China; studies that are underpinned by rigorous theoretical, empirical, and prescriptive processes. The contemporary literature on policy-oriented learning can be divided into three categories: problem recognition, solution identification, and organizational engagement. Each addresses policy-oriented learning processes that influence public sector reforms and policy adoption.

Problem recognition in policy-oriented learning is closely related to the public's and professionals' dissatisfaction with the poor performance or irrelevancy of an existing policy [24]. Learning includes gaining knowledge, positive and negative experiences, and the outcomes associated with certain policy content, design, goals, instruments, and approaches [29]. Zhang proposed that problem recognition is a self-evaluation process and usually emerges through a new policy agenda that is introduced due to a structural change in government organizations, institutional administrations, and/or the hierarchy of public organizations [16]. Alternatively, problem recognition may be viewed as a political strategy aimed at reforming situations for which political orientations have already been set. In summary, problem recognition is the first step, or the "diagnostic and admission step" [30]. Different factors may be responsible for policy failures and thus highlight the need for change, as the American political scientist Charles Jones argued,"the source of all policy failures is politics", which is an essential first step in recognition. Yet, is politics the source of all policy failures [31]? Farazmand questioned whether other unexpected "nonlinear or chaotic and dynamic sources" could also affect policy failures [30].

Policy academics use policy-oriented learning to explain the significance of exogenous policies, institutional ideologies, or administrative approaches that fulfill the condition of promoting indigenous administrative development. It is a meritocratic approach that emphasizes the function of governmental sectors as agents that seek solutions to existing 
public problems [24]. Contemporary studies on identifying a solution primarily focus on four factors: (1) whether the reform process of an exporting country would advise an importing country to achieve the political goals they pursue; (2) whether resource features, such as environmental and technological issues, include a process of achieving political goals that have been achieved by other institutions; (3) whether the fundamental legal and social structures are similar in both the donor and recipient countries; most importantly, (4) whether the goals of policy-oriented learning are in accordance with the cultural values, ethics, and will of the people in the recipient countries [22]. Bennett used policy-oriented learning as a unique term to explain why a particular policy is adopted. His work on the learning of policy goals, matters, and approaches clarified three phases of policy-oriented learning: (1) problems with existing policies are identified; (2) information and knowledge about the various options are compared; (3) a particular solution is adopted to satisfy the general public and professionals [28].

The impact of organizational engagement is considerable during the policy-oriented learning process. Three observations should be highlighted. First, the use of professional knowledge about research institutions and international organizations helps to legitimize the process of administrative reform. Policy-makers not only concentrate on the experiences and lessons of developed countries, but also turn to the regulations and guidelines of international organizations such as the WHO, World Bank, the OECD, and the UN. These organizations have increasingly and distinctly impacted the ability to sustain states during a transitional period as they explore best practices or preferred policies when reforming their economy and public sector. Second, official and unofficial structural opportunities for policy-oriented learning, plus the endogenous and exogenous sources of learning, are created to facilitate a wide range of policy changes. Third, policy-oriented learning leads to other forms of learning that are determined by the organizations who engage in the learning process and the nature of the existing problems. Thus, policy-oriented learning can be a rational and progressive knowledge-transferring activity if the knowledge, policy, program, and administrative settings learned are compatible with the norms, values, and institutional structure of the recipient organization. These organizations, including governmental departments and NGOs, are the determining factors in engineering policy changes. Successful policy-oriented learning is enriched by recognizing the importance of agents. Policy-oriented learning matters because it shapes the nature of policy outcomes and emerges from the organization's engagement in the process of learning. In this sense, it can have a momentum of its own through functionality [21,24].

\section{Understanding China's LTCI Policy as a Process of Policy-Oriented Learning}

The implementation of the pilot program aimed to assess whether LTCI can facilitate a new approach to China's social security system in providing care to the elderly and disabled. Consequently, its impacts are commonly recognized as positive. However, policy-oriented learning should be verified in a more systematic assessment of initiating LTCI. In this research, Evans' [21] voluntary policy-oriented learning framework was employed to examine the nature and outcomes of the LTCI initiation process in China (see Box 1). Five stages were examined, including problem recognition, search for ideas, and contact; the emergence of an information feeder network; cognition, reception, and the emergence of policy-oriented learning; elite and cognitive mobilization; evaluation, decision, and implementation. 
Box 1. The voluntary policy-oriented learning framework. Source: [21].

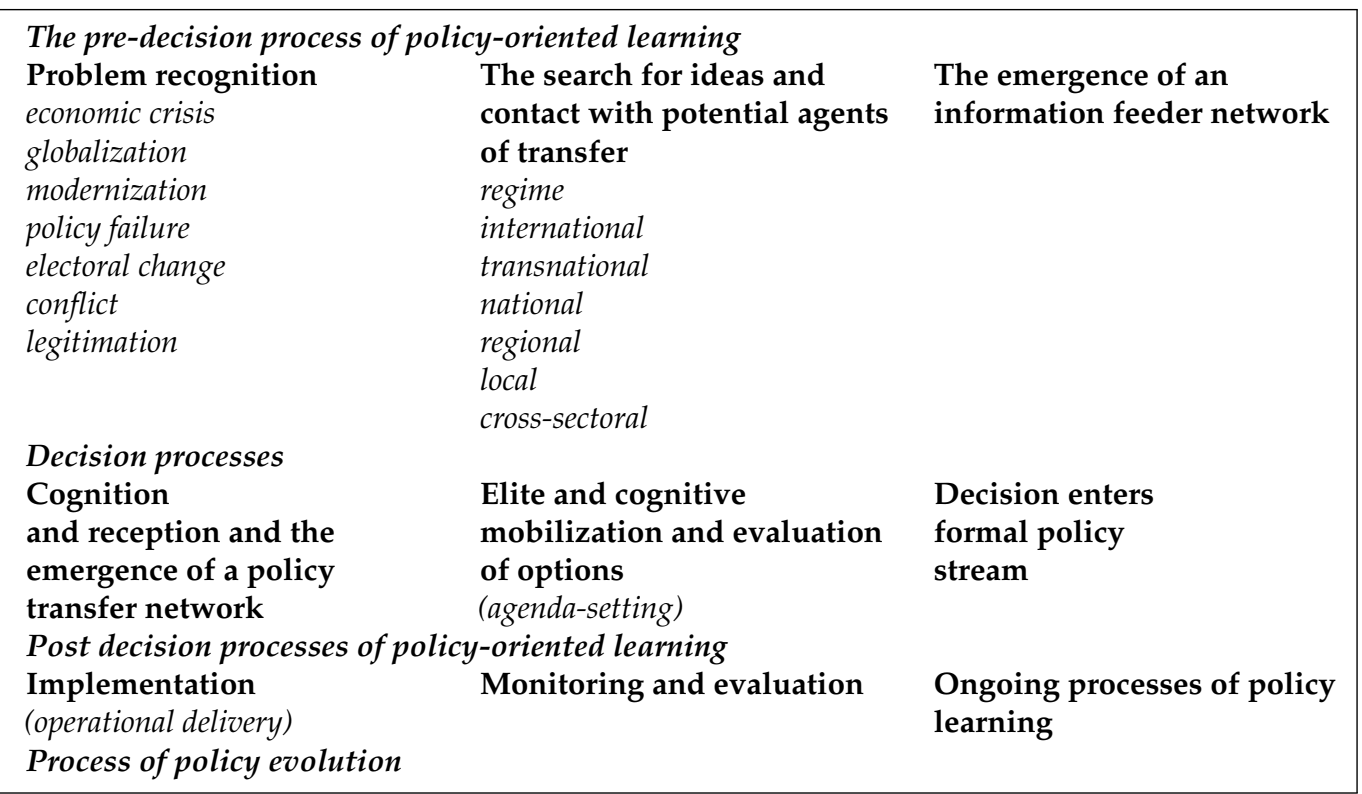

\subsection{Problem Recognition}

The One-Child Policy limited the increase in population in the short term, and caused new demographic issues and an aging problem in Chinese society. Since the presidency of Jiang Zemin, establishing LTCI to care for the elderly and disabled has become vital to developing the social security sector in China. However, the LTCI pilot program was officially implemented in 2016. The main aim of the initiative was to rationalize the administrative relationship, streamline organizational functions, increase accountability of governmental departments, decrease the financial and physical burden of citizens, and improve patients' quality of life by using a modern initiative that addresses demographic problems [2].

\subsection{Search for Solutions and Contact}

The Chinese government has searched for exogenous solutions to the problem of an aging society since the turn of the new millennium. During the search process, the MOHRSS compared successful and unsuccessful programs delivered by different nations, and the German program gradually became the first choice as the source of learning. The German LTCI system has three main components: (1) Social LTCI (SLTCI), which covered $86.7 \%$ of the population in 2017; (2) private LTCI (PLTCI), which covered $11.3 \%$ of the population in 2017 (both SLTCI and PLTCI were established through the Pflege-Versicherungsgesetz in 1994); (3) the supplementary care insurance system, which was established in 2013. Approximately $2-3 \%$ of the population has participated in the supplementary LTCI system [32]. Moreover, the characteristics of Germany's demographic issues are similar to those of China. Hence, its lessons and experiences have attracted considerable attention from Chinese policy-makers and political elites.

However, both the German social security sector and the Chinese MOHRSS acted as the main organizations engaged in the learning process. The MOHRSS actively organized a summit, academic conference, and study tour in the contact stage. Through communication between elites and experts, the German elites and experts demonstrated their knowledge and gained access to Chinese professionals. Consequently, the MOHRSS relied on a policy importer and played a vital role in introducing German lessons into China to contribute to the initiation process. 


\subsection{Cognition, Reception, and Emergence of Policy-Oriented Learning}

By observing and studying the German initiative, the MOHRSS improved its understanding of how the German social security sector handles aging issues. They also developed a common aim for China's LTCI to assist the social security sector in providing care to the disabled and elderly. As Zhang emphasized, the international organization such as WHO, World Bank, the OECD, and the UN, has created, directly or indirectly, a new structural opportunity for policy-oriented learning [16]. Given the lessons from Germany, and in line with the problems of Chinese social security and the need of the Chinese government, the MOHRSS was appointed to respond to the initiation of LTCI. The MOHRSS was concerned with two issues during the pilot process. The first was the compatibility of the Chinese organization. Although the lessons and policy implementation of the German social security sector are advanced, a direct duplication of the German experience was not encouraged during the initiation process of China's LTCI. Second, the pilot program of China's LTCI in the 15 cities was essentially a trial-and-error sum of domestic experiences. Both international experiences and domestic circumstances are universal but have their own particularities. Therefore, in the process of formulating LTCI localization, the solution should be learned from its universality, while understanding and adapting to particularities.

\subsection{Elite and Cognitive Mobilization}

In 1997, the issue of long-term care was debated at the Fifteenth National Congress of the Communist Party. This exacerbated the initiation process of LTCI in China. As Zhang and Marsh stated, as the main agents involved in the policy-oriented learning process, bureaucratic elites should have the same objectives, common norms, and values as the policy that needs to be learned exogenously [24]. In an interview with Dong Keyong [33], he argued that it is difficult to identify whether the lessons of the German social security sector and LTCI can lead to a resolution, as despite having similar demographic characteristics, the countries have different cultural and political contexts. He also emphasized that as China is a big country with 56 national cultures and a huge area of land, the policy needs to cautiously examine local circumstances.

\subsection{Evaluation, Decision, and Implementation}

The agents involved in the processes of policy-oriented learning were satisfied with the extent of the information collecting in which they had engaged. However, implementation proved more difficult. China is a huge country with 56 nations and national ethnicities. Piloting the programs in certain cities had been the main, and almost the only, approach for implementing LTCI in China. At the same time, different pilot cities had their own authority to implement the LTCI system. In short, surveys of the general public opinion are the only reference data that can evaluate the outcomes of LTCI.

\section{Evaluating the Performance of China's LTCI in Pilot Cities}

In the winter of 2017, the authors began a survey investigation to evaluate the outcomes and performance of China's LTCI. The aim of this survey was to evaluate the satisfaction rate in the pilot program of LTCI, and then to assess the feasibility of official implementation of LTCI in China. This study was supported by the Bureau of Human Resources and Social Security, the Insurance Regulatory Bureau, and the Civil Affairs Bureau. The survey was administered to 1500 individuals who were covered by the pilot program of China's LTCI, with a $77.8 \%$ effective response rate $(1167 / 1500)$. The characteristics of the survey are shown in Table 2. 
Table 2. Definitions and descriptions of variables included in the survey $(N=1167)$.

\begin{tabular}{|c|c|c|c|c|}
\hline Variable & Measurement & Min. & Max. & Percentage $(N)$ \\
\hline Sex & $\begin{array}{l}1=\text { Male } \\
2=\text { Female }\end{array}$ & 1 & 2 & $\begin{array}{l}47.0 \%(548) \\
53.0 \%(619)\end{array}$ \\
\hline Age & $\begin{array}{l}1=60-69 \\
2=70-79 \\
3=80-89 \\
4=90-99 \\
5=100 \text { and Above }\end{array}$ & 1 & 5 & $\begin{array}{l}29.8 \%(348) \\
39.4 \%(460) \\
23.0 \%(268) \\
6.6 \%(77) \\
1.2 \%(14)\end{array}$ \\
\hline Degree of Disability & $\begin{array}{l}1=\text { Not At All } \\
2=\text { Partly Disable } \\
3=\text { Severe Disable } \\
4=\text { Completely Disable }\end{array}$ & 1 & 4 & $\begin{array}{l}15.2 \%(177) \\
19.5 \%(227) \\
41.8 \%(488) \\
23.6 \%(275)\end{array}$ \\
\hline Choices of Care & $\begin{array}{l}1=\text { At Home } \\
2=\text { Local Community } \\
3=\text { Nursing House } \\
4=\text { Hospitals }\end{array}$ & 1 & 4 & $\begin{array}{l}71.6 \%(835) \\
4.8 \%(56) \\
12.1 \%(141) \\
11.6 \%(135)\end{array}$ \\
\hline Living Location & $\begin{array}{l}1=\text { Western Cities } \\
2=\text { Inner China Cities } \\
3=\text { Eastern Coast Cities }\end{array}$ & 1 & 3 & $\begin{array}{l}17.7 \%(207) \\
31.4 \%(366) \\
50.9 \%(594)\end{array}$ \\
\hline Number of Children & $\begin{array}{l}1=0 \text { child } \\
2=1 \text { child } \\
3=2+\text { children }\end{array}$ & 1 & 3 & $\begin{array}{l}10.1 \%(118) \\
81.2 \%(947) \\
8.7 \%(102)\end{array}$ \\
\hline Monthly Income & $\begin{array}{l}1=0-999 \text { RMB } \\
2=1000-1999 \text { RMB } \\
3=2000-2999 \text { RMB } \\
4=3000-4999 \text { RMB } \\
5=5000-7999 \text { RMB } \\
6=8000 \text { RMB and Over }\end{array}$ & 1 & 6 & $\begin{array}{l}17.0 \%(198) \\
23.8 \%(278) \\
17.6 \%(205) \\
18.0 \%(210) \\
15.6 \%(182) \\
8.1 \%(94)\end{array}$ \\
\hline Degree of Satisfaction & $\begin{array}{l}1=\text { Satisfied } \\
2=\text { Neutral } \\
3=\text { Dissatisfied }\end{array}$ & 1 & 3 & $\begin{array}{l}72.2 \%(843) \\
7.9 \%(92) \\
19.9 \%(232)\end{array}$ \\
\hline
\end{tabular}

All the statistical analyses were two-sided and performed using SPSS (17.0 Version SPSS Inc., Chicago, IL, USA) and STATA (14 MAC Version Stata Corp, College Station, Texas, USA), and the statistical significance was set to $p<0.05$.

The results of this survey were that $72.2 \%$ (843 people) were satisfied; $7.9 \%$ (92 people) expressed a neutral attitude toward LTCI; and 19.9\% (232 people) were displeased with LTCI as a pilot policy [2]. This has crucial implications for the aging society and social sector's reform. Furthermore, these findings support the outcomes of policy-oriented learning, when engaging in the process of initiating LTCI in China (see Table 3)

Table 3 provides the results of the ordered logistic regression analysis, including the coefficient, standard deviation, $p$-value, and confidence interval. The table shows the basic characteristics of the distribution of effective responses to the survey. Significant relationships between living location and number of children of the family and the outcomes and performance of the LTCI policy can be seen in Table 3. The issues of sex, age, degree of disability, choices of care, and monthly income are also revealed in Table 3; however, the results were not significant $(p>0.05)$. Moreover, people living in the western cities reported higher levels of satisfaction than those living on the east coast. People without children were more satisfied than those with two or more children, people with one child were more satisfied than people with two or more children, and people without children were more satisfied than people with one child. 
Table 3. Coefficient of ordinal logit regression of the survey in China's LTCI $(N=1167)$.

\begin{tabular}{|c|c|c|c|c|c|c|}
\hline Variables & Satisfied (\%) & Neutral (\%) & Dissatisfied (\%) & Coefficient (S.E.) & $p$-Value & $95 \% \mathrm{CI}$ \\
\hline $\begin{array}{l}\text { Gender } \\
\text { Male } \\
\text { Female }\end{array}$ & $\begin{array}{l}391(71.3 \%) \\
452(73.0 \%)\end{array}$ & $\begin{array}{l}41(7.5 \%) \\
51(8.3 \%)\end{array}$ & $\begin{array}{l}116(21.2 \%) \\
116(18.7 \%)\end{array}$ & $\begin{array}{c}0.165(0.136) \\
0\end{array}$ & 0.222 & $-0.100-0.431$ \\
\hline $\begin{array}{c}\text { Age } \\
60-70 \\
70-80 \\
80-90 \\
90-100 \\
100+\end{array}$ & $\begin{array}{c}259(74.4 \%) \\
332(72.2 \%) \\
183(68.3 \%) \\
60(77.9 \%) \\
9(64.3 \%)\end{array}$ & $\begin{array}{c}23(6.6 \%) \\
34(7.4 \%) \\
28(10.4 \%) \\
2(2.6 \%) \\
5(35.7 \%)\end{array}$ & $\begin{array}{c}66(18.0 \%) \\
94(20.4 \%) \\
57(21.3 \%) \\
15(19.5 \%) \\
0(0.0 \%)\end{array}$ & $\begin{array}{c}0.050(0.630) \\
0.117(0.627) \\
0.302(0.632) \\
-0.141(0.676) \\
0\end{array}$ & $\begin{array}{l}0.937 \\
0.851 \\
0.633 \\
0.834\end{array}$ & $\begin{array}{l}-1.186-1.286 \\
-1.000-1.345 \\
-0.936-1.540 \\
-1.466-1.183\end{array}$ \\
\hline $\begin{array}{c}\text { Degree of disability } \\
\text { Not at all } \\
\text { Partly disable } \\
\text { Severe disable } \\
\text { Completed disable }\end{array}$ & $\begin{array}{l}124(70.1 \%) \\
163(71.8 \%) \\
346(70.9 \%) \\
210(76.4 \%)\end{array}$ & $\begin{array}{l}15(8.5 \%) \\
17(7.5 \%) \\
39(8.0 \%) \\
21(7.6 \%)\end{array}$ & $\begin{array}{c}38(21.4 \%) \\
47(20.7 \%) \\
103(21.1 \%) \\
44(16.0 \%)\end{array}$ & $\begin{array}{c}0.298(0.224) \\
0.193(0.217) \\
0.214(0.186) \\
0\end{array}$ & $\begin{array}{l}0.184 \\
0.374 \\
0.251\end{array}$ & $\begin{array}{l}-0.142-0.738 \\
-0.233-0.619 \\
-0.151-0.579\end{array}$ \\
\hline $\begin{array}{l}\text { Choice of care } \\
\text { Home } \\
\text { Local community } \\
\text { Nursing house } \\
\text { Hospitals }\end{array}$ & $\begin{array}{c}595(71.3 \%) \\
41(73.2 \%) \\
100(70.9 \%) \\
107(79.2 \%)\end{array}$ & $\begin{array}{l}72(8.6 \%) \\
2(3.6 \%) \\
9(6.4 \%) \\
9(6.7 \%)\end{array}$ & $\begin{array}{l}168(20.1 \%) \\
13(23.2 \%) \\
32(22.7 \%) \\
19(14.1 \%)\end{array}$ & $\begin{array}{c}0.389(0.241) \\
0.300(0.394) \\
0.412(0.300) \\
0\end{array}$ & $\begin{array}{l}0.107 \\
0.447 \\
0.169\end{array}$ & $\begin{array}{l}-0.083-0.861 \\
-0.472-1.072 \\
-0.176-1.000\end{array}$ \\
\hline $\begin{array}{c}\text { Monthly income } \\
\text { 0-999 RMB } \\
\text { 1000-1999 RMB } \\
\text { 2000-2999 RMB } \\
\text { 3000-4999 RMB } \\
\text { 5000-7999 RMB } \\
\text { 8000 RMB and above }\end{array}$ & $\begin{array}{c}140(70.7 \%) \\
195(70.1 \%) \\
150(73.2 \%) \\
143(68.1 \%) \\
140(92.1 \%) \\
75(79.8 \%)\end{array}$ & $\begin{array}{l}16(8.1 \%) \\
26(9.4 \%) \\
13(6.3 \%) \\
19(9.1 \%) \\
10(6.6 \%) \\
8(8.5 \%)\end{array}$ & $\begin{array}{c}42(21.2 \%) \\
57(20.5 \%) \\
42(20.5 \%) \\
48(22.8 \%) \\
2(1.3 \%) \\
11(11.7 \%)\end{array}$ & $\begin{array}{l}0.461(0.309) \\
0.429(0.297) \\
0.344(0.308) \\
0.593(0.305) \\
0.129(0.318) \\
0\end{array}$ & $\begin{array}{l}0.135 \\
0.149 \\
0.265 \\
0.052 \\
0.685\end{array}$ & $\begin{array}{l}-0.144-1.066 \\
-0.154-1.011 \\
-0.261-0.948 \\
-0.004-1.190 \\
-0.494-0.752\end{array}$ \\
\hline $\begin{array}{c}\text { Living area } \\
\text { Western cities } \\
\text { Inner China cities } \\
\text { Eastern Coast cities }\end{array}$ & $\begin{array}{l}169(81.6 \%) \\
262(71.6 \%) \\
412(69.4 \%)\end{array}$ & $\begin{array}{c}9(4.4 \%) \\
24(6.5 \%) \\
59(9.9 \%)\end{array}$ & $\begin{array}{l}29(14.0 \%) \\
80(21.9 \%) \\
123(20.7 \%)\end{array}$ & $\begin{array}{c}-0.654^{* * *}(0.203) \\
-0.083(0.152) \\
0\end{array}$ & $\begin{array}{l}0.001 \\
0.588\end{array}$ & $\begin{array}{c}-1.052 \text { to }-0.257 \\
-0.381-0.216\end{array}$ \\
\hline $\begin{array}{c}\text { Number of children } \\
0 \text { children } \\
1 \text { child } \\
2+\text { children }\end{array}$ & $\begin{array}{c}78(66.1 \%) \\
714(75.4 \%) \\
51(50.0 \%)\end{array}$ & $\begin{array}{c}10(8.5 \%) \\
69(7.3 \%) \\
13(12.8 \%)\end{array}$ & $\begin{array}{c}30(25.4 \%) \\
164(17.3 \%) \\
38(37.2 \%)\end{array}$ & $\begin{array}{c}-0.603^{* *}(0.279) \\
-1.064^{* * *}(0.211) \\
0\end{array}$ & $\begin{array}{c}0.03 \\
0\end{array}$ & $\begin{array}{l}-1.149 \text { to }-0.057 \\
-1.477 \text { to }-0.651\end{array}$ \\
\hline Observations & \multicolumn{6}{|c|}{$N=1167$} \\
\hline Degree of freedom & \multicolumn{6}{|c|}{20} \\
\hline
\end{tabular}

Note: ${ }^{* * *} p<0.01$ and ${ }^{* *} p<0.05$. Source: [2].

\section{Conclusions}

The LTCI policy was introduced to relieve the problems caused by an aging society and associated factors in China. It has also led to the improvement of China's social security sector by using a policy-oriented learning framework. Scrutiny of the lessons learned from Germany's long-term care policy reveals a perfect case of policy-oriented learning. Moreover, this detailed exploratory study shows how policy-oriented learning has been used to address the promotion of the LTCI policy in China. The analysis suggests that the LTCI policy is the production of a policy-oriented learning framework in China. Moreover, the outcomes of this policy instrument are positive and acceptable by Chinese public values.

This study concerned three research questions: (1) What is the situation and characteristics of China's aging problem?; (2) Can policy-oriented learning be used as a rational tool to solve the problem of China's aging society?; (3) Is the LTCI policy a product of policy-oriented learning in China? To answer the first question, this study highlighted that issues related to China's aging society were mainly caused by the One-Child Policy and new demographic patterns. Although the One-Child Policy was abandoned in 2016, China's aging society has not changed. Without reform and development in both governmental organizations and the social security sector, China's aging problems will likely be irreversible. For the second research question, this study further observed that a 
policy-oriented learning framework is a rational tool that can be used to solve the problems of China's aging society. This study explored the idea that policy-oriented learning can facilitate a quick solution to satisfy public and professional discontent with the poor performance of an existing policy. For the third question, the LTCI policy is a product of policy-oriented learning, and facilitates the development of China's social security sector.

This study provides four contributions: (1) it explored policy-oriented learning as an approach to creating and implementing an LTCI policy in China; (2) it evaluated policyoriented learning as a tool for developing China's social security sector; (3) it established analytical and methodological variables that can be used to supervise the policy-making process in China; (4) the findings provide an understanding of the initiating process of China's LTCI policy through the lens of a policy-oriented learning framework. This study is the first comprehensive study of a policy-oriented learning framework that assists with the initiation of the LTCI policy in China.

Through investigating the theory and practice of policy-oriented learning and the detailed analysis of China's LTCI, the research concludes that policy-oriented learning is a tool for dealing with public problems. This study explained the process of initiating China's LTCI into the voluntary policy-oriented learning framework, and examined the outcome of its implementation. The pilot program of China's LTCI provides an insight into the Chinese characteristics that affect the process of Chinese administrative reform, especially regarding the development of the social security sector. The findings have important implications for globalization, policy-oriented learning, and international development literature, as policy-oriented learning aims to provide guidance for rational policy-making.

This research has three significant limitations: first, this study only focused on one program, which is China's LTCI. This may not express the complex situation adequately, when policy-oriented learning engages in the process of policy making in China; second, the data collected for this paper were limited and only selected from government sectors; and finally, given the status of the interviewees, the interviews were confidential. Moreover, this study did not collect data from the business sectors, etc. These weaknesses will be addressed in future studies and will be the focus of future research by the author.

Author Contributions: Conceptualization, J.Z. and Y.Z.; methodology, J.Z. and Y.Z.; software, J.Z. and Y.Z.; validation, J.Z. and Y.Z.; formal analysis, J.Z. and Y.Z.; investigation, J.Z.; X.Y. and Y.Z.; resources, J.Z.; X.Y. and Y.Z.; data curation, J.Z. and Y.Z.; writing-original draft preparation, J.Z. and Y.Z.; writing-review and editing, J.Z. and Y.Z.; visualization, J.Z.; X.Y. and Y.Z.; supervision, J.Z.; X.Y. and Y.Z.; project administration, J.Z.; X.Y. and Y.Z.; funding acquisition, J.Z.; X.Y. and Y.Z. All authors have read and agreed to the published version of the manuscript.

Funding: This research was funded by National Natural Science Foundation of China (72074095).

Institutional Review Board Statement: Not applicable.

Informed Consent Statement: Not applicable.

Data Availability Statement: Not applicable.

Conflicts of Interest: The authors declare no conflict of interest.

\section{References}

1. Chai, H.X. Hollowing-out as Statecraft: The Case of Administrative Reform in China. Ph.D. Thesis, Department of Politics, University of York, York, UK, 2009.

2. Zhang, Y.; Yu, X. Evaluation of Long-Term Care Insurance Policy in Chinese Pilot Cities. Int. J. Env. Res. Public Health 2019, 16, 3826. [CrossRef] [PubMed]

3. Yuan, Z.G.; Song, Z. Demographic rate, pension system and saving ratio in China. Econ. Study 2000, 11, 45-52. (In Chinese)

4. Zhang, Y.T.; Goza, F.W. Who will care for the elderly in China? A review of the problems caused by China's One Child Policy and their potential solutions. J. Aging Stud. 2006, 20, 151-164. [CrossRef]

5. National Bureau of Statistics of China. 2019. Available online: http:/ / data.stats.gov.cn/easyquery.htm?cn=C01 (accessed on 3 March 2020).

6. National Bureau of Statistics of China. 2017. Available online: http:/ / data.stats.gov.cn/easyquery.htm?cn=C01 (accessed on 28 February 2020). 
7. Barlett, H.; Phillips, D.R. Ageing and aged care in the People's Republic of China: Nation and local issues and perspectives. Health Place 1997, 3, 149-159. [CrossRef]

8. Blondeau, J.; Dubois, D. Financing old-age dependency in Europe: Towards overall management of old-age. Geneva Pap. Risk Insur. 1997, 22, 46-59. [CrossRef]

9. Flaherty, E.G.; Thompson, R.; Litrownik, A.J.; Theodore, A.; English, D.J.; Black, M.M.; Wike, T.; Whimper, L.; Runyan, D.K.; Dubowitz, H. Effect of Early Childhood Adversity on Child Health. Arch. Pediatr. Adolesc. Med. 2006, 160, 1232-1238. [CrossRef] [PubMed]

10. The Decline in Fertility Rates in China. Available online: http://www.gov.cn/gzdt/2007-01-11/content_492377.htm (accessed on 10 May 2020). (In Chinese)

11. Liu, S.H.; Yang, J.W.; Zhang, Y.J. The actions and responses to China's aging problems. Popul. Res. 1999, 23, 34-41. (In Chinese)

12. Wang, Q.; Zhou, Y.; Ding, X.; Ying, X. Demand for Long-Term Care Insurance in China. Int. J. Env. Res. Public Health 2017, 15, 6. [CrossRef] [PubMed]

13. Yu, Z.; Senior civil servant in the Ministry of Human Resources and Social Security of Liaoning Province, China. Personal communication, 11 June 2019.

14. Zhang, T.; Mayor at Chaoyang City, Liaoning Province, China. Personal communication, 23 March 2019.

15. Xu, Y.; China Academy of Governance. Personal communication, 15 October 2019.

16. Zhang, Y.Z. Police-Oriented Learning and Opening up: The Case of China in Transition. Ph.D. Thesis, Australian-New Zealand School of Government, Canberra, Australia, 2014.

17. Geraedts, M.; Heller, G.V.; Harrington, C.A. Germany's long-term-care insurance: Putting a social insurance model into practice. Milbank Q. 2000, 78, 375-401. [CrossRef] [PubMed]

18. Heclo, H. Modern Social Politics in Britain and Sweden; Yale University Press: New Haven, CT, USA, $1974 ;$ p. 306.

19. Ikenberry, G. The international spread of privatization policies: Inducements, learning and policy "Bandwagoing". In The Political Economy of Public Sector Reform and Privatization; Suleiman, E., Waterbury, J., Eds.; Westview: Boulder, CO, USA, 1990; pp. 88-110.

20. Shipan, C.R.; Volden, C. The Mechanisms of Policy Diffusion. Am. J. Political Sci. 2008, 52, 840-857. [CrossRef]

21. Evans, M. In Conclusion-Policy Transfer in Global Perspective; Routledge: London, UK, 2017; pp. $211-226$.

22. Rose, R. What is Lesson-Drawing? J. Public Policy 1991, 11, 3-30. [CrossRef]

23. Cartwright, N.; Hardie, J. Evidence-based Policy. A Practical Guide to Doing It Better; Oxford University Press: Oxford, UK, 2012.

24. Zhang, Y.; Marsh, D. Learning by doing: The case of administrative policy transfer in China. Policy Stud. 2016, 37, 35-52. [CrossRef]

25. Dolowitz, D.P.; Marsh, D. Learning from abroad: The role of policy transfer in contemporary policy-making. Government 2000, 13, 5-23. [CrossRef]

26. Common, R. Organisational learning in a political environment: Improving policy-making in UK Government. Policy Stud. 2004, 25, 35-97. [CrossRef]

27. Carroll, P.; Common, R. Policy Transfer and Learning in Public Policy and Management; Routledge: Oxford, UK, 2013.

28. Bennett, C.J. How States Utilize Foreign Evidence. J. Public Policy 1991, 11, 31-54. [CrossRef]

29. Dunlop, C.A. Policy learning and policy failure: Definitions, dimensions and intersections1. Policy Politics 2020, 45, 3-18. [CrossRef]

30. Farazmand, A. Governance reforms: The good, the bad, and the ugly; and the sound: Examining the past and exploring the future of public organizations. Public Organ. Rev. 2017, 17, 595-617. [CrossRef]

31. Jones, C. An Introduction to the Study of Public Policy; Brooks/Cole: Pacific Grove, CA, USA, 1984.

32. Wen, Y.Q. Comparison and enlightenment of long-term care insurance system in Germany and Japan. Soc. Secur. World 2020, 3, 31-32. (In Chinese)

33. Dong, K.P.; Renmin University. Personal communication, 23 November 2019. 